\title{
The Global Finical Crisis from an Islamic Point of View
}

\author{
$1^{\text {st }}$ Hewa Majeed Zangana \\ Department of Computer Science, \\ Nawroz University, \\ Kurdistan Region of Iraq \\ Hewa.majeed@nawroz.edu.krd \\ https://doi.org/10.48161/qaj.v1n2a39
}

\begin{abstract}
When the world economy suffered a new financial economic crisis, it uncovered to the world that there were major failures within the Industrial financial system and it was caused by a number of issues including the practice of interest and the terrible effect it has on the financial crisis events. Issues that will be discussed in this paper are Riba, Gambling, Uncertainty, Derivatives, Saucerization, Sell of debt, Creation of Money, and the Private "Personal" interests. However, the paper will focus on the Islamic financial system and the financial instruments which are based and designed in compliance with Shariah Rules and Regulations, whether if practicing Islamic banking would cause such a crisis to accrue.

The Sukuk, of the Islamic mortgage-Backed securities $(M B S)$, and Islamic future contract will be discussed in order to prove why using the Islamic Financial system is better to assure that this kind of global crisis doesn't come to pass again.
\end{abstract}

Keywords: Financial, Economic, Crisis, Riba, Sukuk

\section{INTRODUCTION}

The economy of world has not tasted a universal financial crisis since the 1930s [3]. However, in 2008 the world financial economy was hit by another crisis [2]. On 18 of September, the system of international financial was on the edge of collapsing, and the credit global of markets ceased essentially its activities for the four weeks followed [2].

Where the impact of ultimate economic of the crisis of financial and the credit of Global Crisis of 2008 is until now unknown [7], it followed by a number of events dramatically consisting the losing of most institutions of financial and government interventions significantly in the systems of financial all over the world. Nowadays [16], it is not likely that either any major domestic or the global system of financial will collapse, which was the cause of the depression of economic seen in the late 30s of last century [14]. The causes of the credit crisis of global are now taken an idea from the Islamic point of view; however, a major investigation is in progress all over the world to regain the regulation of financial, with reaching for the procedures for the global finance of future.
This crisis has without a doubt shocked the American people in the very principles they had in the economic liberalism, which had failed them [13], and it approved that letting all things to the market's regulations without any supervision and control causing catastrophes strikes in the middle of the economy known as macro to be a result of the greedy capitalists' unruly desires. Nowadays [14], the whole world has become as a victim because of this crisis because of some Wall Street traders' gambles. The best way to describe the cause of the current crisis as a root against the word 'gambling,' that was invented by many parties, beginning with the policy makers of monetary which are shown by the financial institutions, Board of Federal Reserve, borrowers and brokers.

However, no one focusing on the reality which is that the disaster was not depending on a fact economic product it is on a numerous of debts of inflated. Securities, derivatives, bonds, hedging contracts and options in the secondary market have being traded [11].

\section{RIBA}

Iَ وَأَحَلَّ) (Rslam has prohibited usury (Riba), Allah Said [1], but the capitalist system scientists have gone so far in the use of riba or interest, and put theories to justify its legitimacy, but the capitalist theories didn't a prove that capital return, but the yield may be in the form of interest, or in the form of a share of the profit, or in any other forms.

The term Loan in the Islamic perspective is meant for the purpose of righteousness and virtue [12]; the borrower can lighten some or all of the payment. In forward sales or Instalments, there may be a price passed in Islam that is deferred as a higher expedited or can be authorized, as the scholars state it as time share price. However, if the price deferred from debit so there will be a payment deficit which is not approved in Islam.

It is important that interest in capitalist economy theories were able to prove that capital returning, but it failed to prove that revenue could be in the form of interest. This practice of having interest resulted in the occurrence of the financial crisis. Finally, be aware that Islam does not say that there is such a thing as a zero-interest rate. In consumer credit, financing of production there is no a zero-interest rate, but a percentage of profits will be suitable. 


\section{GAMBLING \& UNCERTAINTY}

Gambling is also forbidden in Islam, but the capitalism routine endorsed lotteries and competitions in the area of stock exchanges, etc. Also, the stock exchange is just a club (casino) gambling exchange processes mostly based on the speculation of prices, such speculation would lead to the stock assessment in the stock market with more than their real value, or much lower [20].

The exchange contracts are unlikely to illustrate what the seller has sold, and what the buyer would buy, but it is merely betting on profits from futures contracts (gambling), which is neither delivered nor received, but it is settling accounts where the price differentials. This created a fabricated economy far from the speculative real economy.

Moreover, the small investors profit from lottery, based not on the financial analysis and study budgets, it is not capable of achieving its goal, even if it used with some analysts, these analysts are not responsible, they cheat and deceive him without any liability or conscience. Moreover, major investors in the stock market deceive the young ones, and drain their savings, leading them to bankruptcy. However, the stocks exchange markets practice some illegal and unethical ways to clear stock, same as the legitimate market (liquidation) stock and the financing of projects, without engaging in speculation, betting, gambling, deceit and deception. All practices are unproductive processes and harmful where in case of some gain the others are losing "unfairness".

\section{DERIVATIVES}

Future contracts driven from any stock exchange are called derivatives and swaps, exchanging options because the option value is derived from the other. It is used mostly in speculation of prices. Some Westerners says it is a tool of mass destruction, or a time bomb that is set to explode at any moment, they also describe it as a constitute tool for gambling or betting, it is also separated from the original risk of a relationship, then the risk becomes a commodity being traded, which leads to sharp fluctuations in the financial markets and the manufacture of collapses, bubbles, and crises [17].

\section{SECURITIZATION}

Securitization can be defined as a representation of asset backed securities tradable equities that is called securitization. If we assume that there is a commodity that has been securitized, it can trade their securities independently. There is no doubt that the Securitization helps large circulation, but also help the speculation of prices, without delivery or receipt of the item, but the item remains in place, and could be fake or virtual. Perhaps the main idea of securitization is to share the company's capital and shareholders, helping them to sell their shares and buy other's shares in the company, without the necessitate to liquidate the company, and it also helps to achieve the stability of the company's capital and converting the shares into cash if necessary [15].

However, these shares can be used as a mean of speculation on prices, until they share a different value from the real value, which reflects the origin of a common share in the net assets of the company.

What is important here is that the wave of oversecuritization with no doubt helped to separate the financial economics from the real economy, which has reached a very high value.

\section{SELL OF DEBT}

The operations of conventional banks are based on trading in debt (loans) and cash. The Bank borrows money based on interest, and lends the money based on a higher interest, making the profit from the difference between the two rates [12].

The conventional banks can impose interest on loans, increase interest on delaying payment or reimbursement. The debt can also be sold to a second person, third and fourth, this many accumulated debts, but this is the week point in the capitalist system, that creates mountains (or pyramids) of debt, the delay in payments or omission, it may cause a possible collapse in these mountains, and a disaster that will lead to a major crisis for sure.

In summary, the causes of the current global crisis are trading debt, debt sale, expansion, and we won't forget the role of credit cards. If the goal is to get to the bottom of this crisis, it must put an end to these debt trading.

\section{CREATION OF MONEY}

The central bank issues the money both notes and coins, banks create money banking credit (written) or cash deposits. If the banks keep deposits and depositors with entrust to any bank money creation, this means that banks are keeping a full cash reserve but in fact these banks retain partial incomplete cash reserve and lender over the reserve [9].

The banking system can double bank deposits and money multiplier, capitalization and deposits received, achieving more profits and interest, the technical rules taken into account banks apply in granting credits, regulations, that are monitored by the Central Bank [4].

There is a risk in the process of creating money and credits. In recent years, it was noted that banks tend to encourage consumption, credit cards and personal loans to home buyers and real estate speculation in the stock market. There is no doubt that this major credit expansion, with the lack of supervision, is one of the major causes of the current crisis.

\section{THE PRIVATE (PERSONAL) INTERESTS}

Capitalist system usually focuses on the pursuit of the individual's own benefit, and thus dominated by special interests, public interests and charitable interests, leading to overstatement, exaggeration, extremism, irregularities, illegal and immoral issues. Islam didn't prevent a special interest, but Islam believes that the majority of the economic and financial Muslim scholars have their own interests as a minor thing but if the private interest interferes with the public interest, the public interest claim superiority. This means that individuals and companies are encouraged to observe the public interest, which can be put in the form of laws and regulations that can let the public engage in their own interest's process [5][8].

The previous mentioned points above are some of the core reasons for the present financial crisis, the questions that is forcing itself now, can the similar disaster happen in a regulated market and controlled by the Shariah of Islam.

The answer of course is no; with this degree of magnitude of disaster could not happen in any markets supervised by the Shariah of Islam because transmissions in 
the Shariah of Islam are depending on the exchange of utilities in reality and goods. The law of Islam does not allow outlaws the selling and usury of what you don't own except under conditions of strict like the commodities' selling which the price is fully paid in advance where "the product" is postponed which its valuated, where it reduces the transaction risks in it.

Islamic Shariah does not allow and forbids as well the buying and selling in the case of postponement "contracts which forwarded", which is similar to the case with contracts of derivative and trading's debt but when it is done under some specific conditions which does not allow the deceit, manipulation and usury. Because of these reasons, scholars of the Shariah have condoned trading in derivatives and securities of all types, where is also shows why some institutions of Islamic financial have not been caused by the crisis [12][17].

The current crisis and those that are similar to it highlights the ingenious of Shariah of Islam and the wisdom of the Almighty with these types of transactions in prohibiting, also it demonstrates the need of human to follow the inspiration of this Shariah that bring well to all humanity. This crisis puts on those in charge of Islamic banking a huge burden to invent Islamic tools of banking depending on the Sunnah "Prophetic traditions" and the Quran away from reproducing and cloning the current conventional tools of banking, for providing solutions that are effective to this economy that has been suffering for long because of its dependence on error and trial of human.

\section{ISLAMIC FINANCIAL SYSTEM}

The most main aims of Islam are achieving a justice in great form in the society of human. A society where there is no justice is doomed to rot and die. Many rules are needed for justice and values of ethic that are acceptable for everybody also it is bound by a strong society. The financial system can raise the level of justice if the strength and stability are prerequisites and available. These both conditions depend on the values of moral and one of them is which the employer uses his own money to participate in risk, so he won't carry all the burden of losses to the organization [15][7].

The second condition is that the financial institutions have to allocate a fair share of financial resources for the poor and needy people, in order to help fighting poverty, increasing number of workers, and increasing opportunities for self-employment, and then reduce the disparities in income and wealth. To achieve that Islam has to organize the shares and funds of profits and losses fairly. This helps to introduce more disciplinary role in the financial system, stimulating the financial institutions to construct more concern and attention to risk assessment and control over the borrowers use of funds.

This dual participates of risk conducted where the taxpayers and where the organizers must assist injecting in the system more discipline, also mitigate a large extent from lending over. The finance of Islam, in its model which is ideal, strives to contribute a large extent in order to raise the share capital, as well as the shares in the profits and losses.

However, the increased dependence and confidence on the finance capital does not necessarily mean the exclusion of debt financing. This is due to all of the needs of individuals of financial, governments and enterprises could not be met by finance capital and funding alone. In doing so, religion is indispensable, but it shouldn't expand the consumption of unnecessary and wasteful consumption, and in the sterile non-productive speculation. For this reason, shariah principles didn't allow the Islamic financial system to create borrowing and through direct lending a debt, but requested the initialization of debt by selling assets and to rent, through the existing methods of financing the sale or lease (Istisna, Ijara, Murabaha, Sukuk, and Salam).

The point and goal are to enable individuals and enterprises that are now buying real goods and services necessary according to their ability to pay in the future. However, some conditions should be applied, including:

i. Original Sales or lessor must be real, not an imaginary or a default.

ii. The seller owns a leased or the goods sold.

iii. Religion cannot be sold, and therefore the risk associated with it should be borne by the lender itself.

iv. The offering treatment to be a commercial transaction in a genuine form, along with every receipt of delivery and intention.

Kind of financial instruments are the Islamic Financial Instruments which are designed and based on compliance with Regulations and Shariah Rules. The main kinds of Instruments of Islamic Financial are: Sukuk, mortgageBacked securities (MBS) of Islam, and Islamic future contract.

The "Sukuk" here first was intended for instruments of the financial of Islam of Islamic Development Bank in the year of 2002 in the Islamic financial jurisprudence session. The meaning of Sukuk is certificates with nominal value in the form of identical, then after finishing of the operations of subscription of the evidence payment by the purchaser to the issuer of a nominal amount mentioned in it; and the holder of it shall be beneficiary of a project or a special investment activity or the owner of a set of assets or profits arising from assets (Source: AAOIFI) [2]

Sukuk differ in terms of maturities (short, medium, long-term) or by the form (Mudarabah, Musharakah, Ijara, Salam, and Istisna). Islamic bonds "Sukuk" are consider as the Islamic alternative to conventional bonds.

Certificates of Sukuk serve to tradable securities in resources mobilization from markets and to replicate the functions of conventional bonds while providing a stable resource of income for investors there is the injecting liquidity into the enterprise or government. Moreover, Sukuk differ from bonds of conventional and asset securitizations in different forms:

i. Sukuk are directly linked with real sector activities. Sukuk's Investing in issuances involves the funding of trade or production of tangible assets Hence these will not create short-term speculative movement of funds and potential financial crises.

ii. Capital gains are accumulated when fixed-rate bond prices rise as variable market indices fall. Conventional investors in corporate and government bonds hope to capitalize on favorable developments in interest rates. The legitimacy of Sukuk structures in the Shariah lie in the fact that they do not take advantage of interest rate movements. 
iii. Sukuk investors have an inherent right to information on the use of their investments, nature of the underlying assets, and other particulars that would otherwise be considered redundant in conventional investments. This will help introduce discipline in the market.

Issuing of Sukuk includes a set of procedures and they are:

i. Work out and achieving a good structure of Shariah to get the numerous objectives with Shariah in compliance.

ii. Preparing feasibility study in details (achieving and stating clear objectives from the proposed compliant business of Shariah) and setting up of general framework and organizational structure to support the issuance process.

iii. Upsetting the SPV to show Sukuk holders which are the investors and putting into circulation the Sukuk [19].

iv. Managing documentation of form legal around the agreed structure of Shariah (both from the arranger's perspective as well as Issuer's).

v. Arranging lead the managers to underwrite the Sukuk issue.

\section{ASSESSMENT OF THE SUKUK STRUCTURES}

The market for Sukuk has introduced a gigantic need for a scope that can define the management of liquidity in banks of Islam [10]. Long time ago, like this liquidity could only be secured by using the Murabaha transactions in continuous. Where conventional finance dominates in a global market, could only be acquired liquidity by limited transactions to special acceptable commodities of Shariah like goods of industrial, oils and metals. Issuing certificates of Sukuk and its process authorize financial institutions of Islam were previously either inefficient or inaccessible to garner a much wider asset pool.

Anyway, some of the sovereign and corporate Sukuk prospectuses have come under increased scrutiny for their Shariah suitability. The feature of predominant of many of the prospectuses is the floating rate return distributed to the certificate holders. The reference of market used is the Inter-bank of London Offer Rate which called (LIBOR) through that a premium competitive is added. However, LIBOR serves as a market reference for the returns and the intrinsic distributions arise from the rentals pertaining to the leasing arrangements with the originator and SPV, it should be observed that in the case of the Ijara Sukuk arrangements.

The issuance of Sukuk by the IDB serves as a promising and excellent example for arrangements in future. The prospectus contained precise and clear considerations of Shariah outlined by various scholars leading and it contained an innovative portfolio combination of Istisna, Ijara, projects and Murabaha. As well as returns were not ambiguously related to benchmarks of market but were agreed upon a fixed rate of return on the relevant contracts and assets [19].

One dimension of the paradigm of Islamic finance that should not be lost upon compromises for increased profitability is altruism. In this regard, the Sukuk prospectuses have not only mobilized previously untapped public sector funds but have also introduced long sought funding for development projects.

Qatar has funded a large medical complex (Hamad Medical City) in Doha and the Malaysian Sukuk certificates raised funds for several government owned hospitals as well as offices. Most significantly, the IDB Sukuk prospectuses raised funds for projects in 21 developing nations in a wide range of schemes that included power transmissions, hospitals, steel manufacturing, mineral water networks, livestock breeding, sea port development, pharmacology research, agricultural irrigation, telecommunications projects, rural development and colleges [14].

\section{THE CHALLENGES OF ECONOMICS OF SECURITIZATION IN ISLAM}

By taking growing, demand and considerable of compliant assets of shariah, the Sukuk's further development based on infrastructural condition, regulatory and essential economic.

In a context of low reliance on capital market funding in many Islamic countries, Sukuk issuers are first and foremost faced with several critical economic obstacles related to their ability to:

i. Identify benchmark assets that meet Sharia requirements and offer attractive returns.

ii. Replace standard structural features in conventional securities structures, such as credit enhancement and liquidity support, which are not permitted in an Islamic context.

Given the limited supply and structure of qualifying asset portfolios, Islamic issuers have started to build their own Islamically acceptable assets rather than buying pools of assets in the market.

However, the Sukuk market is still plagued by secondary market illiquidity, with the combination of a high concentration of originators and regional fragmentation obscuring the overall positive outlook. Although the concept of asset support is inherent in Islamic finance, structured credit transactions are rare where financial transactions must follow the dictates of Shariah law.

The current level of Sukuk issuance by corporations and public sector entities still remains a fraction of the global fixed income market. Given that only a handful of large banks and managers are at the origin of the bulk of transactions carried out by a small number of regular issuers, the origination and challenges to diversification of investors. In addition, the lack of information from private sources on securitized assets in many Sukukes and the prevalence of "buy and hold" investments impede effective price discovery and information dissemination [10].

An even more important diversification problem arises from the low diversity of assets, given the narrow range of transaction types and maturity periods of the existing market. Sukuk are available for 3-, 5- and 10-year maturities [9], but not for short term maturities, which severely limits their application in the money market. Although Islamic banks are currently among the biggest buyers of Sharia-compliant products, they would benefit the most from the short-term problems. There is some hope that the launch of different Sukuk funds in the near future could potentially be constraints, but it could only create new demand without sufficiently mitigating the supply 
contraction. It is currently also difficult to create Sukuk funds with sufficient diversification.

\section{CONCLUSION}

There is no doubt that the beginnings of Islamic bonds (Sukuk) issued by a number of Islamic governments are also a sign, no one worries that the success of issuing of these Sukuk should replace conventional bonds.

The most important characteristic of these Sukuk is that they reflect on the list of assets owned by the government and therefore governments cannot Exceed the limit of borrowing in contrast to conventional bonds, which is clearly evident in the persistence of Governments issued.

The speculation that bonds may be issued by private companies in the form of investment vehicles, for individuals and it is almost a supporter of capital companies. It should be noted that the time has come to develop a scientific program that can draw attention to the Islamic Economics as a policy applied by both governments' (Public Sectors) and privet sectors that is neither easy nor complex economic concept that can overtake the world of economy.

\section{REFERENCES}

[1] Ali Arsalan Tariq, M.Sc. International Banking, MANAGING FINANCIAL RISKS OF SUKUK STRUCTURES, Copyright AA Tariq, September 2004.

[2] C. Stephanou, THE FINANCIAL CRISIS, Financial Services Liberalization Workshop, Day 3, The World Bank, Malaysia, 5 November 2008

[3] Douglas WArner, The Global Credit Crisis of 2008: Causes and Consequences. The International Lawyer. Chicago:Spring 2009.

[4] Dr. Foo Check-Teck following his Channel News, Asia interview on Tuesday, September 18, 2007 in Singapore. Conceptual lessons on financial, strategy following the US, sub-prime crisis, Check-Teck Foo www.emeraldinsight.com/1526-5943.htm,

[5] Jobst winter 2009. Islamic securitization after the subprime crisis and reas.

[6] Justice Mufti Muhammad Taqi Usmani. POSTCRISIS REFORMS, Some points to ponder.

[7] King Abdul-Aziz University many researchers 2009, the global financial crisis seasons and solving from Islamic point of view.

[8] Lahem al Nasser, The Mortgage Crisis - An Islamic View 09/10/2008

[9] NIDAL A ALSAYYED PhD Researcher Islamic Economics, Banking, and Finance Sukukization: Islamic Economic Risk Factors in Shari'ah View, http://groups.google.com/group/nidal_islamicfinance, Retrieved on $8^{\text {th }}$ February, 2021.

[10] What is

Sukuk?, http://www.sukuk.me/news/articles/73/What-isSukuk-.html Retrieved on $16^{\text {th }}$ February 2021.

[11] Ahmed, A. (2010), "Global financial crisis: an Islamic finance perspective," International Journal of Islamic and Middle Eastern Finance and Management.

[12] Todorof, M. (2018, August), "Shariah-compliant fintech in the banking industry," In ERA Forum (Vol. 19, No. 1, pp. 1-17). Springer Berlin Heidelberg.
[13] Sun, H., Rabbani, M.R., Sial, M.S., Yu, S., Filipe, J. A., and Cherian. J. (2020). "Identifying Big Data's Opportunities, Challenges, and Implications in Finance." Mathematics 8(10).

[14] Reuters, T. (2017), Islamic Finance Development Report 2014. Thomson Reuters.

[15] Rabbani, M.R., Khan, S., Thalassinos, I.E. (2020), "FinTech, Blockchain and Islamic Finance: An Extensive Literature Review," International Journal of Economics and Business Administration, 8(2), 65-86.

[16] Rabbani, M. R. (2020), "The competitive structure and strategic positioning of commercial banks in Saudi Arabia," International Journal on Emerging Technologies 11(3), 43-46.

[17] Poon, J. P., Pollard, J., \& Chow, Y. W. (2018), "Resetting neoliberal values: lawmaking in Malaysia's Islamic finance," Annals of the American Association of Geographers, 108(5), 1442-1456.

[18] KPMG (2017), “The Fintech Imperative: How financial institutions are embracing Fintech to evolve and grow," Available at: https://assets.kpmg/content/dam/kpmg/ke/pdf/thoug htleaderships/Forging-with\%20bleeds.pdf, Accessed on $14 / 06 / 2020$.

[19] IFDI (2018), Islamic Finance Development Report 2018; Available at; https://ceif.iba.edu.pk/pdf/Reuters-Islamicfinancedevelopment-report2018.pdf. Accesses on $11 / 06 / 2020$.

[20] Alzubaidi, I. B., \& Abdullah, A. (2017), "Developing a Digital Currency from an Islamic Perspective: Case of Blockchain Technology, "International Business Research, 10(11), 79-87. 